\title{
Spirit of Make in India for Rural Prosperity through Dairying in Telangana
}

\author{
Madhusudana Rao* \\ Deputy Director, TSDDCF, Mahbubnagar, India

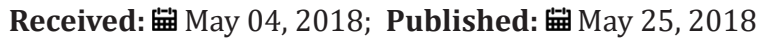 \\ *Corresponding author: Madhusudana Rao, Deputy Director, TSDDCF, Mahbubnagar, India
}

\begin{abstract}
Dairying in India is not just a large economic activity but also an integral part of our social and cultural heritage. Trusting capabilities of our farmers and integrating them with superior, even imported, technology, feed and fodder is the way ahead. The sector requires renewed attention and investments from Government and agricultural research and development community. The Dairy business provides employment to the landless and land owners alike and the income thus generated checks urban to rural migration. In addition, milk, being a complete nutrition, will play a key role in combating malnutrition and poverty. India's market potential and current growth rate of traditional dairy products is unmatched. Reconfiguration of the supply chain will not only require introduction of technology for large scale manufacture but also a second intervention in terms of a business model to expand the demand of traditional products in future and upscale their quality standards. Foreign firms have been closely examining Telangana's suitability as a destination for foreign direct investment (FDI). With a population of 35,286,757 and a GDP of $\$ 53.9$ billion, there is ample room in India's newest State for exceptional growth. The industrial policy framework is driven by the slogan. In Telangana Innovate, Incubate, And Incorporate". The industrial policy announced by the Government provides a business regulatory environment where doing business would be as easy as shaking hands. It is expected that the most significant outcome of this approach will be the production of high quality VIJAYA milk products at the most competitive price, which establishes "Made in Telangana - Made in India as a brand with has already attained high global recognition.
\end{abstract}

\section{Introduction}

Dairying in India is not just a large economic activity but also an integral part of our social and cultural heritage. Trusting capabilities of our farmers and integrating them with superior, even imported, technology, feed and fodder is the way ahead. The sector requires renewed attention and investments from Government and agricultural research and development community. The Dairy business provides employment to the landless and land owners alike and the income thus generated checks urban to rural migration. In addition, milk, being a complete nutrition, will play a key role in combating malnutrition and poverty. The Indian model of milk production is characterized by low input-low output. Despite lack of water and gradually declining arable land, dairy farming is on the rise. This has been made possible by optimal integration of production unit (the cow), technologies and equipment, operator (the farmer) and production environment (the dairy farm). Apart from a well-conceived strategy for increasing productivity of milch animals through superior breeding, nutrition and health practices such as the National Dairy Plan, we need to learn from the best practices across the world. For instance, Israel's Super Cows that produce 12,000 liters milk a year are the result of advanced feed, technology and breeding practices. Thus, trusting capabilities of our farmers and integrating them with superior, even imported, technology, feed and fodder is the way ahead. Make in India is an initiative of the Government of India, to encourage companies to manufacture their products in India. The government's flagship campaign intended to boost the domestic manufacturing industry and attract foreign investors to invest into the Indian economy with an intention of reviving manufacturing businesses and emphasizing key sectors in India amidst growing concerns that most entrepreneurs are moving out of the country due to its low rank in ease of doing business ratings. The manufacturing industry currently contributes just over $15 \%$ to the national GDP. The aim 
of this campaign is to grow this to a $25 \%$ contribution as seen with other developing nations of Asia.

According to worldwatch.org there are 1.7 billion members of "the consumer class" nearly half of them in the developing world. In 2014, Prime Minister Shri Narendra Modi launched what would be another revolution in the making. 'Make in India' is the new mantra and the objective was to encourage the production of goods within the country. The government is taking several initiatives and running plans and programs like National Diary Plan and Intensive Dairy Development Program to meet the growing demand for milk in the country. Following its separation from Andhra Pradesh in June 2014, foreign firms have been closely examining Telangana's suitability as a destination for foreign direct investment (FDI). With a population of $35,286,757$ and a GDP of $\$ 53.9$ billion, there is ample room in India's newest state for exceptional growth.

\section{Status of Dairying in Telangana}

The Government of India has notified Andhra Pradesh Reorganization Act 2014 (Act 6 of 2014) and notified June 2nd 2014 as the appointment day. Accordingly, the state was bifurcated into two states i.e Andhra Pradesh and Telangana. Telangana is blessed with rich livestock resources especially Cattle and Sheep population accounting to $5.52 \%$ of Country's population. The State stands $10^{\text {th }}$ in Livestock population 1 st in Sheep population, $12^{\text {th }}$ in Goat population, 5th in Poultry, 13th in Bovine population and Table 1. $17^{\text {th }}$ in Pig population, in the country as per the Livestock Census, 2007. About 29 Lakh families in Telangana State are engaged in livestock sector for their livelihood. The value of livestock produce is estimated to be Rs. 30584 crores at current prices and Livestock contributes $7.1 \%$ to the Gross State Domestic Product and formed $39.69 \%$ of the Agriculture sector in 2014-15(Advance Estimates). The per capita availability of milk at $234 \mathrm{gm} /$ day in the state and has to catch up with the national average of $263 \mathrm{gm} /$ day even of 2009-10. The state of Telangana has the adequate number of milch animals and the overall productivity from the milch animals is around 105.06 LLPD. The district wise Milch animal population is furnished here under (Table1). The erstwhile district wise availability of milk (LLPD), share of milk procurement by various players in the Telangana is given below (Table 2). As can be seen from the table above, out of total milk production of 105.06 LLPD, 46.18 LLPD (44\%) is consumed by69 the rural household for their day-to-day needs and there is a marketable surplus of 58.88 LLPD (56\%). From out of marketable surplus of 58.88 LLPD, only 12.86 LLPD (22\%) is being tapped by the organized sector and 46.03 LLPD $(78 \%)$ of marketable surplus is still handled by the vendors as part of un-organized sector. Also, it is on record that, the Cooperatives are procuring 4.65 LLPD (1.61 LLPD by TSDDCF, 3.04 LLPD by Milk Unions) and private dairies are procuring 8.21 LLPD. Though there is availability of milk the APDDCF ltd., is not in a position to procure the milk because of price war.

\begin{tabular}{|c|c|c|c|c|c|c|c|c|}
\hline \multicolumn{9}{|c|}{ District wise Milch Animal Population in Telangana } \\
\hline \multirow{3}{*}{ S. No } & \multirow{3}{*}{ District } & \multicolumn{3}{|c|}{ Cattle } & \multicolumn{3}{|c|}{ Buffaloes } & \multirow[t]{2}{*}{ Grand Total } \\
\hline & & Cross Bread & Non Descriptive & Total & Murrah & Non Descriptive & Total & \\
\hline & & $\begin{array}{c}\text { No. of } \\
\text { Animals in } \\
\text { Milk (in 000) }\end{array}$ & $\begin{array}{l}\text { No. of Animals } \\
\text { in Milk (in 000) }\end{array}$ & $\begin{array}{c}\text { No. of } \\
\text { Animals in } \\
\text { Milk (in 000) }\end{array}$ & $\begin{array}{c}\text { No. of } \\
\text { Animals in } \\
\text { Milk (in 000) }\end{array}$ & $\begin{array}{l}\text { No. of Animals } \\
\text { in Milk (in 000) }\end{array}$ & $\begin{array}{c}\text { No. of } \\
\text { Animals in } \\
\text { Milk (in 000) }\end{array}$ & $\begin{array}{c}\text { No. of } \\
\text { Animals in } \\
\text { Milk (in 000) }\end{array}$ \\
\hline 1 & Mahabubnagar & 25.105 & 106.329 & 131.434 & 60.686 & 152.799 & 213.485 & 344.919 \\
\hline 2 & Rangareddy & 19.724 & 49.160 & 68.884 & 53.032 & 75.425 & 128.457 & 197.341 \\
\hline 3 & Hyderabad & 5.866 & 4.346 & 10.213 & 17.189 & 9.341 & 26.530 & 36.743 \\
\hline 4 & Medak & 18.519 & 96.445 & 114.964 & 68.478 & 103.375 & 171.853 & 286.816 \\
\hline 5 & Nizamabad & 18.610 & 52.201 & 70.811 & 33.280 & 105.662 & 138.942 & 209.753 \\
\hline 6 & Adilabad & 17.179 & 152.604 & 169.782 & 37.334 & 93.391 & 130.724 & 300.507 \\
\hline 7 & Karimnagar & 32.633 & 52.800 & 85.433 & 106.853 & 218.162 & 325.015 & 410.448 \\
\hline 8 & Warangal & 17.082 & 70.422 & 87.504 & 61.888 & 148.516 & 210.404 & 297.908 \\
\hline 9 & Khammam & 29.122 & 99.381 & 128.503 & 83.395 & 133.887 & 217.282 & 345.785 \\
\hline \multirow[t]{2}{*}{10} & Nalgonda & 27.949 & 87.332 & 115.281 & 101.035 & 215.386 & 316.420 & 431.701 \\
\hline & Total & 211.788 & 771.02 & 982.808 & 623.169 & 1255.94 & 1879.11 & 2861.921 \\
\hline
\end{tabular}

\section{Table 2.}

\begin{tabular}{|c|c|c|c|c|c|c|c|c|c|c|}
\hline \multirow[b]{2}{*}{ S.No } & \multirow[b]{2}{*}{ District } & \multirow{2}{*}{$\begin{array}{c}\text { Milk } \\
\text { Production }\end{array}$} & \multirow{2}{*}{$\begin{array}{c}\text { Local } \\
\text { Consumption }\end{array}$} & \multirow{2}{*}{$\begin{array}{l}\text { Marketable } \\
\text { Surplus }\end{array}$} & \multicolumn{2}{|c|}{ Milk Procurement (LLPD) } & \multicolumn{3}{|c|}{ Dairy } & \multirow{2}{*}{$\begin{array}{l}\text { Private } \\
\text { Sector }\end{array}$} \\
\hline & & & & & Unorganized & Organized & APDDCF & $\begin{array}{c}\text { Milk } \\
\text { Unions }\end{array}$ & Total & \\
\hline 1 & Mahabubnagar & 10.87 & 4.35 & 6.52 & 4.82 & 1.70 & 0.60 & 0.20 & 0.80 & 0.90 \\
\hline 2 & Rangareddy & 8.14 & 4.88 & 3.25 & 2.93 & 0.33 & 0.01 & 0.27 & 0.27 & 0.05 \\
\hline
\end{tabular}




\begin{tabular}{|c|c|c|c|c|c|c|c|c|c|c|}
\hline 3 & Hyderabad & 2.13 & 1.70 & 0.43 & 0.43 & 0.00 & 0.00 & 0.00 & 0.00 & 0.00 \\
\hline 4 & Medak & 11.04 & 4.42 & 6.62 & 3.93 & 2.69 & 2.32 & 0.00 & 0.32 & 2.37 \\
\hline 5 & Nizamabad & 8.09 & 3.23 & 4.85 & 3.66 & 1.19 & 1.28 & 0.00 & 0.28 & 0.91 \\
\hline 6 & Adilabad & 8.38 & 5.03 & 3.35 & 2.38 & 0.97 & 0.02 & 0.00 & 0.02 & 0.95 \\
\hline 7 & Karimnagar & 16.15 & 6.46 & 9.69 & 7.69 & 2.00 & 0.01 & 1.19 & 1.20 & 0.80 \\
\hline 8 & Warangal & 10.77 & 4.31 & 6.46 & 5.83 & 0.63 & 0.30 & 0.20 & 0.50 & 0.13 \\
\hline 9 & Khammam & 13.71 & 5.36 & 8.04 & 6.30 & 1.74 & 0.06 & 0.20 & 0.26 & 1.48 \\
\hline 10 & Nalgonda & 16.10 & 6.44 & 9.66 & 8.05 & 1.61 & 0.01 & 0.98 & 0.99 & 0.61 \\
\hline & Total & 105.06 & 46.18 & 58.88 & 46.03 & 12.85 & 1.61 & 3.04 & 4.65 & 8.21 \\
\hline
\end{tabular}

VIJAYA Dairy's presence has been limited to Mahabubnagar, Warangal, Khammam, Nizamabad and Adilabad after its erstwhile arm Mother Dairy expanded operations in Ranga Reddy and Nalgonda with Central assistance and the Dairy Farmers Federation monopolized its position in Karimnagar. In view of the great potential for milk in the newly formed Telangana State and in order to make the Milk Products Factory (Telangana Federation) to be self reliance in terms of milk processing, packaging and marketing wholesome milk and milk products, intensified focus is required in developing the Dairy Infrastructure. Further, for the overall development of the dairy sector, it is decided that the Dairy Development activities in the state have to be taken up in coordination and convergence with AH Dept., for strengthening and over all development of dairy activities with a view to intensify the coverage of network and to increase the milk procurement to become self sufficiency.

\section{Steps taken to increase milk procurement in Cooperative sector by Govt. of Telangana}

The Telangana Government approved Rs.4 incentive to be given to farmers who supply milk to the cooperative (Figure 1). The scheme was announced in October 2014 and being implemented since November, 2014. The scheme is encouraging to dairy farmers to supply milk to Cooperative rather than to private firms. In Telangana, Vijaya Dairy procures four lakh litres a day against 12 lakh litres by private dairies, mainly Tirumala, Heritage, Dodla and Jersey. The scheme has been extended to Karimnagar milk union, Mulknoor dairy and NARMUL from September, 2017 (Figure 2). The industrial policy framework in Telangana is driven by the slogan "In Telangana Innovate, Incubate, and Incorporate". The industrial policy announced by the Government provides a business regulatory environment where doing business would be as easy as shaking hands. It is expected that the most significant outcome of this approach will be the production of high quality goods at the most competitive price, which establishes "Made in Telangana-Made in India" as a brand with high global recognition. Industrialization in the services sector, where the State has an advantage, is likely to get a boost with the approval of the Government of India for establishment of Information Technology and Investment Region (ITIR). Another major national project which has been taken up in Telangana is the National Investment and Manufacturing Zone (NIMZ) in Medak district and Hyderabad for promoting manufacturing in the State and setting of chasing cell in CM secretariat.
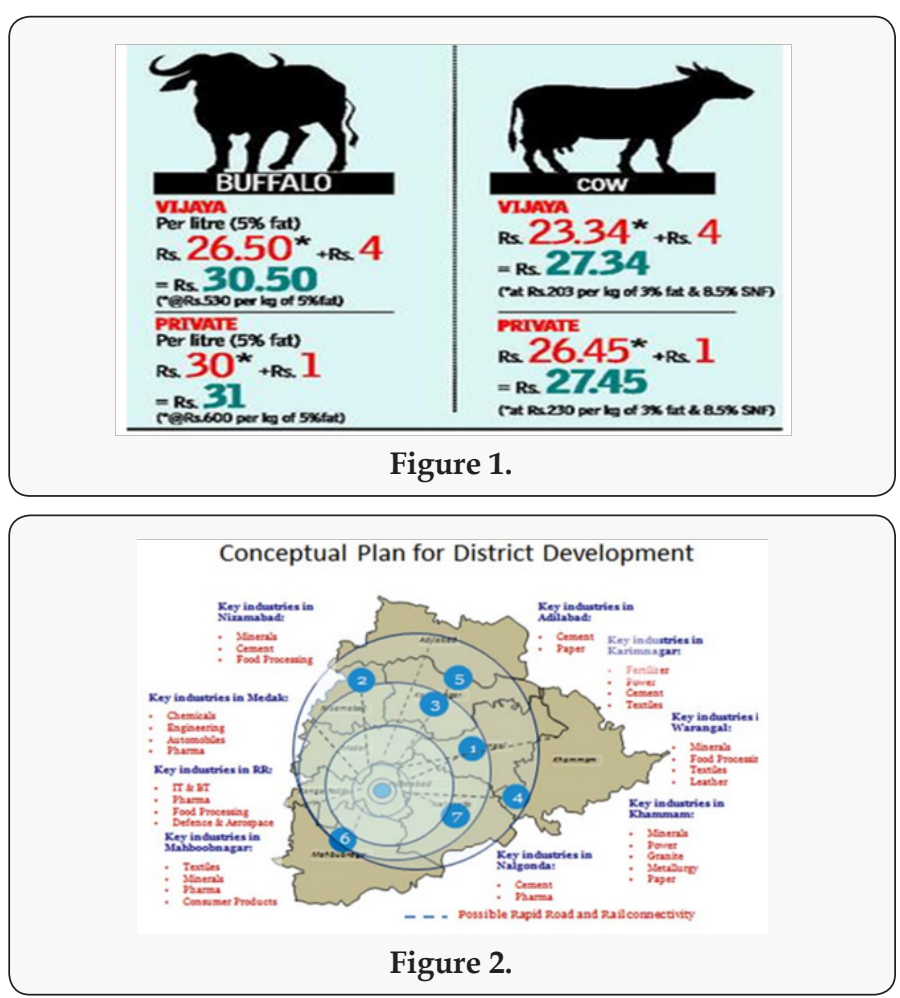

The Government of Telangana State is determined to create an ecosystem in which the ease of doing business in the state matches and even exceeds the best global standards. The Government has enacted the "Telangana State Industrial Project Approval and Self Certification System (TS-iPASS) Act, 2014" (Act No.3 of 2014) repealing the AP Industrial Single Window Clearance Act 2002 for speedy processing of applications\& for issue of various licenses, clearances and certificates required for setting up of industrial undertakings and also to provide for an investor friendly environment in the State of Telangana, based on the selfcertification by the entrepreneur.

\section{Need of certain interventions in current scenario}

VIJAYA has stood as a brand for quality and trust of consumers. Dairy is synonymous with eradicating rural poverty, building rural economy, providing food and nutritional security. Transparency need to be developed right from purchasing milk from farmer. The system of mobile application developed by NDDB, which will recommend a balanced diet for milch cattle to help boost farmers' income by rising yield and cutting feed cost should be 
popularized. Systematic budgeting and follow up review by Banks for animal husbandry activities should be geared up. The lending by STREENIDHI in the State for milch cattle purchase has to be popularized among women SHGs. The progeny testing of cattle should be simplified and farmer should be able to get SMS alert about the forthcoming dates of vaccination, insemination, pregnancy and time to deliver a calf. There is need of process mechanization and automation in production, processing and packaging of milk and milk products. Every care should be taken for standardization of existing technologies for conservation of water and energy in the dairy processing sector.

The production of ethnic Indian dairy sweets should be taken up on developed, mechanized lines with formulation of mandatory statutory standards for the products. In view of availability of more buffalo milk in the region, the dairy sector is poised to become globally competitive and capture the international market. However to achieve this, there is need to improve the quality and freshness milk and milk products, upgrade the processes and packaging to provide traditional dairy foods with an extended shelf life. In wake of proposed milk grids proposed for Medak District, the production of milk in the region shall gain momentum in coming years, as the Hon'ble CM himself is keenly interested in grounding of the project through TSDDCF. Milk ensures food security and nutritional security including in rural India. If a farmer owns just one milking animal, he will not commit suicide. Milk ensures daily income to him and some food for his family. The distribution of rural income, as reflected in the gini coefficient (the measure of inequality) is very low for the dairy sector, indicating that the ownership and the income are more evenly distributed and the progress in this sector will result in a more balanced development of rural economy. Recovery of low tax through dairy sector should not be considered as a loss to the national exchequer but an investment that would spur growth in milk production, ensuring national food and nutritional security and enhancing rural prosperity. There is the need for creating a price stabilization fund to enable the federation to absorb the additional burden in case of unforeseen exigency in the demand and supply situation. It would be more appropriate to modify the norms of National Dairy Plan so that National Dairy Plan becomes $100 \%$ grant-in-aid programme, so that, the vision of Golden Telangana becomes a reality.

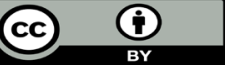

This work is licensed under Creative Commons Attribution 4.0 License

Submission Link:

$$
\text { Submit Article }
$$

DOI: $10.32474 / C D V S .2018 .01 .000120$

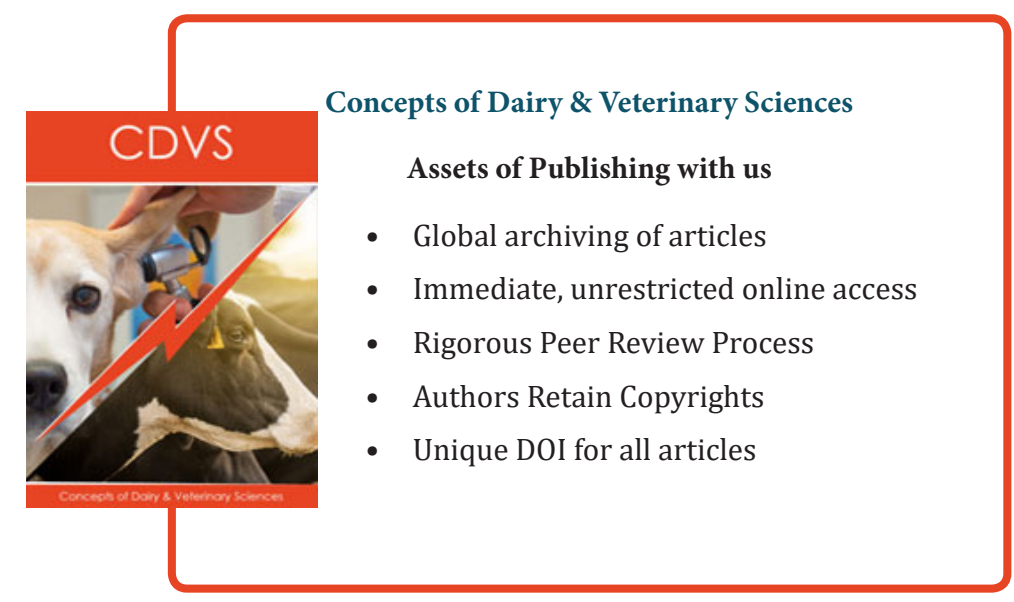

